\title{
Silicon potentiates the activities of defense enzymes in the leaf sheaths of rice plants infected by Rhizoctonia solani
}

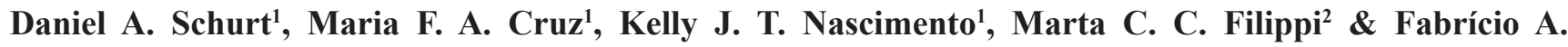 \\ Rodrigues $^{1}$
}

${ }^{1}$ Departamento de Fitopatologia, Universidade Federal de Viçosa, 36570-900, Viçosa, MG, Brazil; ${ }^{2}$ Embrapa Arroz e Feijão, 75375-000, Santo Antônio de Goiás, GO, Brazil

Author for correspondence: Fabrício A. Rodrigues, e-mail: fabricio@ufv.br

\begin{abstract}
This study aimed to assess the ability of silicon ( $\mathrm{Si}$ ) to potentiate defense enzyme activities in rice leaf sheaths and thus reduce sheath blight, caused by Rhizoctonia solani, development. Rice plants of BR-Irga 409 and Labelle cultivars were grown in a hydroponic solution containing $0(-\mathrm{Si})$ or $2 \mathrm{mM}(+\mathrm{Si}) \mathrm{Si}$ and inoculated with $R$. solani. Silicon concentration in the leaf sheaths was significantly higher in the $+\mathrm{Si}$ plants than the -Si plants by $727 \%$ for BR-Irga 409 and $714 \%$ for Labelle. The area under relative lesion expansion progress curve was significantly lower for +Si plants than -Si plants, by $34.2 \%$ for BR-Irga 409 and 30.59\% for Labelle. Increases in the activities of phenylalanine ammonia-lyases, peroxidases, polyphenoloxidases and chitinases in the leaf sheaths of plants supplied with $\mathrm{Si}$, especially of those from BR-Irga 409, led to reduced progress of sheath blight lesions.
\end{abstract}

Key words: Oryza sativa, fungal disease, host defense response, mineral nutrition, sheath blight.

Rice (Oryza sativa L.) is one of the most important carbohydrate sources for the world population, and the occurrence of sheath blight, caused by the necrotrophic fungus Rhizoctonia solani Kühn (teleomorph Thanatephorus cucumeris (A. B. Frank) Donk), has contributed to dramatically decrease yield (Ou, 1985). Severely infected plants produce poorly filled or empty grains, especially those on the lower portion of the panicle (Rush \& Lee, 1992). The occurrence of severe sheath blight epidemics and the consequent reduction in yield have been favored by flood irrigation, rotation with soybeans and the use of high-yielding cultivars that are susceptible to the disease (Bedendo \& Prabhu, 2005).

Sheath blight needs to be managed to prevent yield losses caused by this disease worldwide. Soil amendment with various sources of soluble silicon ( $\mathrm{Si}$ ) has been proposed as an environmentally friendly choice for sheath blight management worldwide (Datnoff et al., 2007). Although $\mathrm{Si}$ is not considered an essential nutrient for plants, it is noted for its potential to decrease the intensity of important diseases in several crops, especially grasses (rice, sorghum and wheat) and some dicots (cucumber and soybean) (Datnoff et al., 2007). The increased blast resistance of rice plants when supplied with $\mathrm{Si}$ has been attributed to a higher density of long and short silicate cells in the leaf epidermis and/or the existence of a thick silica layer below the cuticle forming a physical barrier that prevents or slows Pyricularia grisea penetration (Kim et al., 2002). Increased concentrations of phenolics, lignins and phytoalexins, enhanced activity of defense-related enzymes (chitinases, $\beta$-1,3-glucanases and phenylalanine ammonialyases) and the rapid and strong induction of genes related to host defense against pathogens are the biochemical mechanisms that are potentiated by $\mathrm{Si}$ in rice (Rodrigues et al., 2003, 2004, 2005; Liang et al., 2006; Brunings et al., 2009). This study aimed to determine the effects of Si on the activities of defense enzymes in rice leaf sheaths associated with reduce sheath blight development.

The nutrient solution used to grow the rice plants was prepared based on Hoagland \& Arnon (1950) with some modifications and consisted of $1.0 \mathrm{mM} \mathrm{KNO}_{3}, 0.25$ $\mathrm{mM} \mathrm{NH} \mathrm{H}_{2} \mathrm{PO}_{4}, 0.1 \mathrm{mM} \mathrm{NH} \mathrm{N}_{4} \mathrm{Cl}, 0.5 \mathrm{mM} \mathrm{MgSO}{ }_{4} .7 \mathrm{H}_{2} \mathrm{O}$, $1.0 \mathrm{mM} \mathrm{Ca}\left(\mathrm{NO}_{3}\right)_{2}, 0.30 \mu \mathrm{M} \quad \mathrm{CuSO}_{4} .5 \mathrm{H}_{2} \mathrm{O}, 0.33 \mu \mathrm{M}$ $\mathrm{ZnSO}_{4} .7 \mathrm{H}_{2} \mathrm{O}, 11.5 \mu \mathrm{M} \mathrm{H}_{3} \mathrm{BO}_{3}, 3.5 \mu \mathrm{M} \mathrm{MnCl}_{2} \cdot 4 \mathrm{H}_{2} \mathrm{O}, 0.1$ $\mu \mathrm{M}\left(\mathrm{NH}_{4}\right)_{6} \mathrm{Mo}_{7} \mathrm{O}_{24} \cdot 4 \mathrm{H}_{2} \mathrm{O}, 25 \mu \mathrm{M} \mathrm{FeSO} \cdot 7 \mathrm{H}_{2} \mathrm{O}$ and $25 \mu \mathrm{M}$ EDTA disodium. The $\mathrm{Si}$, which was provided as monosilicic acid, was obtained by passing potassium silicate through a cation exchange resin (Amberlite IR-120B, $\mathrm{H}^{+}$form, SigmaAldrich) (Ma et al., 2002). The Si concentrations used were $0(-\mathrm{Si})$ and $2 \mathrm{mM}(+\mathrm{Si})$. The addition of monosilicic acid to the nutrient solution did not alter the $\mathrm{pH}$.

Rice seeds from the BR-Irga 409 and Labelle cultivars, which are susceptible to $R$. solani (AG-1 IA), were surface-sterilized in $10 \%(\mathrm{v} / \mathrm{v}) \mathrm{NaOCl}$ for $2 \mathrm{~min}$, rinsed in sterilized water for $3 \mathrm{~min}$ and germinated on distilled water-soaked germitest paper in a germination chamber (MA-835/2106UR; Marconi) at $25^{\circ} \mathrm{C}$ for 6 days. These two cultivars were used to determine whether they 
differ in terms of Si uptake and, consequently, in their resistance to sheath blight. The germinated seedlings were transferred to 5 -L plastic pots $(30 \mathrm{~cm}$ diameter) (Ecovaso) with one-half-strength nutrient solution without $\mathrm{Si}$ for two days. After this period, the plants were transferred to new plastic pots with nutrient solution that was prepared with or without Si. The nutrient solution, lacking aeration, was changed every four days. The $\mathrm{pH}$ was checked daily and maintained at approximately 5.5 using $\mathrm{NaOH}$ or $\mathrm{HCl}(1 \mathrm{M})$ when needed.

The isolate UFV-Rs 22 of $R$. solani (AG-1 IA), obtained from symptomatic plants (cv. Metica-1), was used to inoculate the plants. Sclerodia of $R$. solani were preserved on silica gel (Dhingra \& Sinclair, 1995). Wooden toothpicks, $1 \mathrm{~cm}$ in length, were placed in Erlenmeyer flasks containing a shallow layer of potato broth and autoclaved. After autoclaving, 15 toothpicks and five agar plugs (5 $\mathrm{mm}$ diameter) obtained from the margin of an actively growing colony of $R$. solani were transferred to PDA plates. These plates were allowed to incubate for 8 days at room temperature so $R$. solani could colonize the toothpicks (Rodrigues et al., 2001). Plates containing mycelium growing on and also within the toothpicks remained in a growth chamber $\left(25^{\circ} \mathrm{C}\right.$, photoperiod at $12 \mathrm{~h}$ light $)$ for 5 days. The sheaths of the leaves of the plants were inoculated with $R$. solani at 60 days after transplanting (maximum tillering stage). The second sheath of the main stem of each plant was inoculated by placing, with the aid of sterile forceps, a piece of toothpick colonized by the fungus. The inoculated sheaths were tied to the tillers of the plants. Immediately after inoculation, the plants were transferred to a plastic mist growth chamber (MGC) inside a greenhouse for the duration of the experiments. The MGC was constructed of wood ( $2 \mathrm{~m}$ wide, $1.5 \mathrm{~m}$ high and $5 \mathrm{~m}$ long) and covered with $100 \mu \mathrm{m}$-thick transparent plastic. The temperature inside of the MGC ranged from $25 \pm 4^{\circ} \mathrm{C}$ (day) to $21 \pm 2{ }^{\circ} \mathrm{C}$ (night). The relative humidity was maintained at $92 \pm 3 \%$ using a misting system (model NEB-100; KGF), which sprayed mist every 30 min above the plant canopies. The relative humidity and temperature were measured with a thermohygrograph (TH-508; Impac). The maximum natural photon flux density at the plant canopy height was approximately $950 \mu \mathrm{mol} / \mathrm{m}^{2} / \mathrm{s}$. The non-inoculated plants were kept in a separate MGC, but were exposed to the same conditions as were the inoculated plants.

The progress (in $\mathrm{mm}$ ) of the sheath blight lesions on leaf sheaths was measured using an electronic digital caliper (China Suppliers) at 24, 48, 72, 96 and 120 hours after inoculation (hai). The relative length of the lesion (RLL) was calculated by dividing lesion length $(\mathrm{cm})$ by sheath length $(\mathrm{cm}) \times 100$. The length of the sheaths was standardized at $15 \mathrm{~cm}$. Data from RLL were used to calculate the area under relative lesion extension progress curve (AURLEPC) according to Shaner \& Finney (1977).

For biochemical assays, the $3^{\text {rd }}, 4^{\text {th }}$ and $5^{\text {th }}$ leaf sheaths from the apex to the base of the plants from each replication of each treatment were collected at 24, 48, 72 and 96 hai. Leaf samples were also collected from the noninoculated plants $(0 \mathrm{~h})$ to serve as controls. The leaves were individually stored in aluminum foil, rapidly frozen in liquid nitrogen and stored in an ultrafreezer at $-80^{\circ} \mathrm{C}$ for further biochemical assays.

A total of $100 \mathrm{mg}$ of leaf sheath was ground into a fine powder using a mortar and pestle with liquid nitrogen, and oxidative damage to the lipids was estimated as the concentration of the total 2-thiobarbituric acid (TBA)-reactive substances and expressed as equivalents of malondialdehyde (MDA) according to Cakmak\& Horst (1991). The concentration of MDA that formed in each sample was calculated using an extinction coefficient of $155 \mathrm{mM} / \mathrm{cm}$ and the concentration was expressed as nmol MDA/g fresh matter.

To obtain the extracts that were used to determine the activities of peroxidases (POX, EC 1.11.1.7) and polyphenoloxidases (PPO, EC 1.10.3.1), $0.5 \mathrm{~g}$ of leaf sheaths tissue was macerated using a mortar and pestle with liquid nitrogen and polyvinylpyrrolidone (PVP) 2\% (w/v) to obtain a fine powder. The powder was homogenized in $2 \mathrm{~mL} 100 \mathrm{mM}$ potassium phosphate (pH 6.8) containing $1 \mathrm{mM}$ phenylmethylsulfonyl fluoride (PMSF) and $0.1 \mathrm{mM}$ ethylenediaminetetraacetic acid (EDTA). The homogenized material was centrifuged at $12,000 \mathrm{~g}$ for $15 \mathrm{~min}$ at $4^{\circ} \mathrm{C}$ and the supernatant was used for enzyme determination. The POX activity was determined by the oxidation of pyrogallol according to the method of Kar \& Miashra (1976). A molar extinction coefficient of $2.47 \mathrm{mM}^{-1} \mathrm{~cm}^{-1}$ was used to calculate the POX activity (Chance \& Maehley, 1955), which was expressed in $\mu \mathrm{mol}$ purpurogallin produced $\mathrm{min}^{-1} \mathrm{mg}^{-1}$ protein. Throughout the process, the microcentrifuge tubes were covered with aluminum foil to protect the mixture from light oxidation. The PPO activity was determined similarly to that of POX except that hydrogen peroxide was not used in the mixture.

To obtain the extract that was used for the determination of phenylalanine ammonia-lyase (PAL, EC 4.3.1.5) activity, $0.5 \mathrm{~g}$ of leaf sheath tissue was macerated using a mortar and pestle with liquid nitrogen and PVP $(2 \%)$ to obtain a fine powder. The powder was homogenized in $2 \mathrm{~mL} 0.05 \mathrm{M}$ sodium borate (pH 8.3) containing $5 \mathrm{mM}$ $\beta$-mercaptoethanol and $1 \mathrm{mM}$ EDTA. The mixture was centrifuged twice at 7,000 $\mathrm{g}$ for $15 \mathrm{~min}$. The supernatant was used to determine the PAL activity. The reaction was initiated by adding $0.5 \mathrm{~mL}$ of the extract to a mixture containing $2 \mathrm{~mL}$ sodium borate buffer $(\mathrm{pH} 8.8,0.1 \mathrm{M}$ ) and $1 \mathrm{~mL} 100 \mathrm{mM} L$-phenylalanine. The reaction mixture was incubated in a water bath at $30^{\circ} \mathrm{C}$ for $4 \mathrm{~h}$. In the control samples, the extract was replaced with sodium borate buffer. The reaction was stopped by adding $0.1 \mathrm{~mL} 6 \mathrm{~N} \mathrm{HCl}$. The absorbance of the trans-cinnamic acid derivatives was measured in a spectrophotometer at $290 \mathrm{~nm}$ and a molar extinction coefficient of $10^{4} \mathrm{mM} / \mathrm{cm}$ (Zucker, 1965) was used to calculate the PAL activity, which was expressed in $\mu \mathrm{mol} / \mathrm{min}^{-1} / \mathrm{mg}^{-1}$ protein. 
To obtain the extracts that were used for the determination of chitinase (CHI, EC 3.2.1.14) and $\beta$-1,3glucanase (GLU, EC 3.2.1.39) activities, $0.5 \mathrm{~g}$ of leaf sheath tissue was macerated in a mortar and pestle with liquid nitrogen and PVP $(2 \%)$ to obtain a fine powder. The powder was homogenized in $2 \mathrm{~mL}$ buffer consisting of 50 $\mathrm{mM}$ sodium phosphate $(\mathrm{pH}$ 6.5) and $1 \mathrm{mM}$ PMSF. The homogenized material was centrifuged at 20,000 $g$ for 25 min at $4^{\circ} \mathrm{C}$ and the supernatant was used as the extract for enzyme determination. The CHI activity was determined by the method of Roberts \& Selitrennikoff (1988) as modified by Harman et al. (1993). A molar extinction coefficient of 7 $\times 10^{4} \mathrm{mM} / \mathrm{cm}$ was used to calculate the $\mathrm{CHI}$ activity, which was expressed in mol $p$-nitrophenyl produced $\mathrm{min}^{-1} \mathrm{mg}^{-1}$ protein. The GLU activity was determined as described by Lever (1972). The absorbance of the product that was released by GLU was measured at $540 \mathrm{~nm}$ and the GLU activity was expressed in absorbance units $/ \mathrm{min}^{-1} / \mathrm{mg}^{-1}$ protein. All enzyme activity measurements were performed in triplicate. The protein concentration of each sample was determined according to the method of Bradford (1976).

At the end of the experiment, the leaf sheaths that were used to evaluate the progress of the sheath blight lesions were collected, washed with deionized water and dried at $65^{\circ} \mathrm{C}$ for $72 \mathrm{~h}$. Next, the leaf sheaths were ground in a Thomas-Wiley mill with a 40 -mesh sieve. The $\mathrm{Si}$ concentration of the leaf sheaths was determined via a colorimetric analysis involving alkaline digestion of $0.1 \mathrm{~g}$ dry leaf tissue (Korndörfer et al., 2004).

Two $2 \times 2$ factorial experiments with ten replications consisting of two Si concentrations $(0$ or $2 \mathrm{mM}$, hereafter referred to as $-\mathrm{Si}$ and $+\mathrm{Si}$ plants, respectively) and two cultivars (BR-Irga 409 and Labelle) arranged in a completely randomized design were used to evaluate sheath blight lesion progress and the Si concentration of leaf sheaths. Cochran's test for homogeneity of variance (Gomez \& Gomez, 1994) indicated that the data from the two experiments could be pooled for data analysis. Two 2 $\times 2$ factorial experiments with six replications consisting of two Si concentrations and two cultivars with a completely randomized design were used to evaluate the biochemical variables. Each experimental unit consisted of a plastic pot with two plants. Data from all the variables were analyzed via analysis of variance (ANOVA) and the means were compared by Tukey's test $(P \leq 0.05)$ using SAS (version 6.12; SAS Institute, Inc.).

Only the factor Si concentration was significant for the concentration of $\mathrm{Si}$ in leaf sheaths $(P=0.00126)$. The leaf sheath Si concentration was 727 and $714 \%$ higher in the + Si plants from the BR-Irga 409 and Labelle cultivars, respectively, than in the -Si plants of these two cultivars. There was no significant difference between the -Si and + Si treatments regardless of the cultivar (Table 1). The factors $\mathrm{Si}$ concentration and cultivar and the interaction $\mathrm{Si}$ concentration $\times$ cultivar were significant for the AURLEPC. The AURLEPC was significantly lower for the $+\mathrm{Si}$ plants than for the -Si plants by 34 and 31\% for the BR-Irga 409 and Labelle cultivars, respectively. There was no significant difference between the $-\mathrm{Si}$ and $+\mathrm{Si}$ plants regardless of the cultivar (Table 2).

There was no significant difference in leaf sheath MDA concentration in the plants from cultivar BR-Irga 409 regardless of the Si concentration (Figure 1A). A higher leaf sheath MDA concentration occurred at 72 hai in the plants from cultivar Labelle not supplied with Si (Figure 1B). The PAL activity was significantly higher in plants supplied with Si from cultivars BR-Irga-409 and Labelle at 24 and at 24 and 48 hai, respectively, compared to the plants not supplied with Si (Figure 2AB). At 96 hai, there was an increase in PAL activity in the leaf sheaths of plants from cultivar Labelle not supplied with $\mathrm{Si}$ (Figure 2B). The POX activity was higher in leaf sheaths of plants from cultivar BR-Irga 409 supplied with $\mathrm{Si}$ at 0 and 72 hai compared to plants not supplied with Si (Figure 2C). At 48 hai, POX activity was higher in the leaf sheaths of plants not supplied with Si (Figure 2CD). In the leaf sheaths of plants from cultivar Labelle not supplied with $\mathrm{Si}$, the highest POX activity occurred at 0 and 72 hai (Figure 2D). The PPO activity was higher in leaf sheaths of plants from cultivar BR-Irga-409 not supplied with $\mathrm{Si}$ at 24 hai, and it was higher at 48 hai in the leaf sheaths of plants supplied with Si (Figure 2E). There was a significant difference in $\mathrm{CHI}$ activity in the leaf sheaths of plants from cultivar BR-Irga 409 supplied with $\mathrm{Si}$ at 48 and 96 hai compared to plants not supplied with Si (Figure 2G). There was a significant difference in GLU activity in the leaf sheaths of plants from cultivar BR-Irga-409 at 0 hai (Figure 2I). There was no significant difference in the PPO, CHI or GLU activities in the leaf sheaths of plants from cultivar Labelle regardless of the Si concentration (Figure 2FHJ).

The results of the present study not only reinforce the concept that Si can decrease the intensity of diseases in economically important crops such as barley, corn,

TABLE 1 - Concentration of silicon ( $\mathrm{Si})(\mathrm{dag} / \mathrm{kg})$ in the leaf sheaths of rice plants from cultivars BR-Irga 409 and Labelle not supplied (-Si) or supplied (+Si) with silicon $(\mathrm{Si})$.

\begin{tabular}{lcc}
\hline \hline Cultivars & \multicolumn{3}{c}{ Treatments } \\
\cline { 2 - 3 } & $\mathbf{- S i}$ & $+\mathbf{S i}$ \\
\hline BR-Irga 409 & $0.58 \mathrm{aA}$ & $4.22 \mathrm{aB}$ \\
Labelle & $0.61 \mathrm{aA}$ & $4.36 \mathrm{aB}$ \\
\hline
\end{tabular}

TABLE 2 - Area under the relative lesion extension progress curves (AURLEPCs) for sheath blight in the leaf sheaths of rice plants from cultivars BR-Irga 409 and Labelle not supplied (-Si) or supplied $(+\mathrm{Si})$ with silicon $(\mathrm{Si})$.

\begin{tabular}{lcc}
\hline \hline Cultivars & \multicolumn{3}{c}{ Treatments } \\
\cline { 2 - 3 } & $\mathbf{- S i}$ & $+\mathbf{S i}$ \\
\hline BR-Irga 409 & $2821 \mathrm{aA}$ & $1856 \mathrm{aB}$ \\
Labelle & $2432 \mathrm{aA}$ & $1688 \mathrm{aB}$ \\
\hline
\end{tabular}



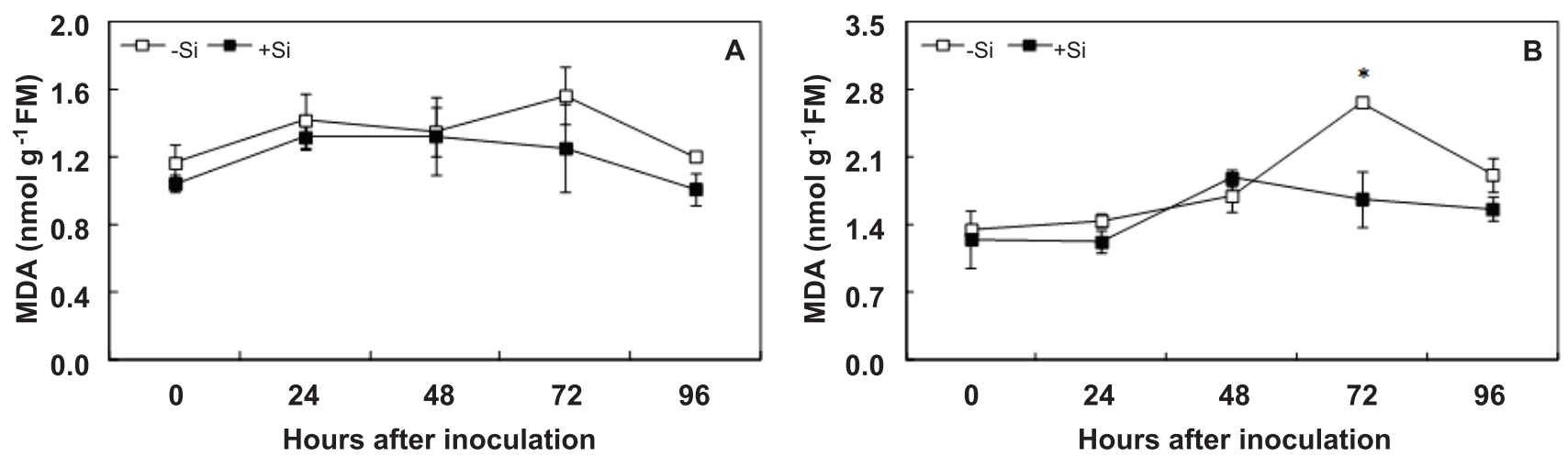

FIGURE 1 - Concentration of malondialdehyde (MDA) in the leaf sheaths of rice plants from cultivars BR-Irga 409 (A) and Labelle (B) not supplied (-Si) or supplied $(+\mathrm{Si})$ with silicon $(\mathrm{Si})$ and inoculated with Rhizoctonia solani. $\mathrm{FM}=$ fresh matter.

cucumber, oats, rice, rye, soybean, sorghum, strawberry and wheat (Bélanger et al., 2003; Datnoff et al., 2007; Dallagnol et al., 2009, Rodrigues et al., 2009), including sheath blight in rice (Rodrigues et al., 2001; Datnoff et al., 2007), but it also provides, to the best of our knowledge, the first biochemical evidence that an increase in the resistance of leaf sheaths against $R$. solani infection can be potentiated by $\mathrm{Si}$.

The Si concentration in the shoots of some monocotyledonous plants such as barley, oats, rice, rye, sugarcane and wheat, can be greater than $5 \mathrm{dag} / \mathrm{kg}$ (Rodrigues et al., 2001; Datnoff et al., 2007; Dallagnol et al., 2009). In the present study, it is plausible that the decrease in the progress of the sheath blight lesions on the plants supplied with Si was due to the high Si concentration. The beneficial effects of $\mathrm{Si}$ in decreasing the intensity of several rice diseases (Datnoff et al., 2007), including sheath blight (Rodrigues et al., 2001; Datnoff et al., 2007), are already well known. Si deposition and polymerization below the cuticle of the rice leaf blades prevent or delay penetration by Pyricularia grisea (Kim et al., 2002). It is known that $R$. solani completely destroys rice leaf cells to obtain the nutrients required to achieve massive growth, and the cellular damage is dramatically enhanced by the diffusion of secreted hydrolytic enzymes and non-host selective toxins into healthy leaf sheath tissue (Ou, 1985). MDA is an indirect indicator of lipid peroxidation in the cell wall membrane. In the present study, lower MDA concentrations were detected in the + Si plants, indicating that $\mathrm{Si}$ amendment most likely affected the ability of $R$. solani to colonize the leaf sheaths and cause cellular damage. Dallagnol et al. (2011) reported that a reduced number of brown epidermal cells in the leaves of rice plants from cultivar Oochikara and the lsil mutant (defective in active Si uptake) supplied with $\mathrm{Si}$ contributed to reductions in lipid peroxidation and electrolyte leakage.

The rice plants that were supplied with Si responded quickly and more effectively to $R$. solani infection possibly because, in areas of heavy Si deposition, a delay in fungal penetration and reduced tissue colonization provided the rice plants with enough time to activate mechanism(s) of defense. The increase in POX, PPO and CHI activities (especially for BR-Irga) and in PAL (especially for Labelle) in the leaf sheaths of plants supplied with Si contributed to reduced sheath blight development during the course of infection by $R$. solani. PAL catalyzes the deamination of $L$-phenylalanine, resulting in the synthesis of various phenolic compounds and phytoalexins, with lignin as the final product (Campbell \& Sederoff, 1996). POX plays a role in the host defense response through the production of antimicrobial quantities of hydrogen peroxide involved in cell wall lignification and by cross-linking with the cell wall proteins (Chittoor et al., 1999; Torres et al., 2006). The active role of $\mathrm{Si}$ in increasing the resistance of rice to blast has been associated with a rapid increase in the concentrations of phenolics and phytoalexins as well as strong and rapid activation of the POX and PR-1 genes (Rodrigues et al., 2003, 2004, 2005). Rodrigues et al. (2005) reported the strong induction of POX transcripts following infection by $P$. grisea, which corresponded to an increase in the concentration of lignin. The leaves of cucumber plants infected by Podosphaera xanthii have also displayed elevated POX activity when supplied with $\mathrm{Si}$ compared to the leaves of untreated plants (Liang et al., 2005). Xavier Filha et al. (2009) further showed that the high POX activity following $P$. grisea infection of leaves of wheat plants supplied with $\mathrm{Si}$ was associated with an increase in the concentration of lignin. In the present study, GLU, in contrast to CHI, did not show any apparent contribution to rice resistance against sheath blight regardless of the Si concentration in leaf sheaths. CHI and GLU are very important enzymes involved in host defenses against pathogen attack due to their capacity to hydrolyze the carbohydrates chitin and $\beta$-1,3-glucan, respectively, which are found in the cell walls of several fungi (Keen \& Yoshikawa, 1983; Mauch et al., 1988).

The results of the present study corroborate the results from other reports regarding the beneficial effects 

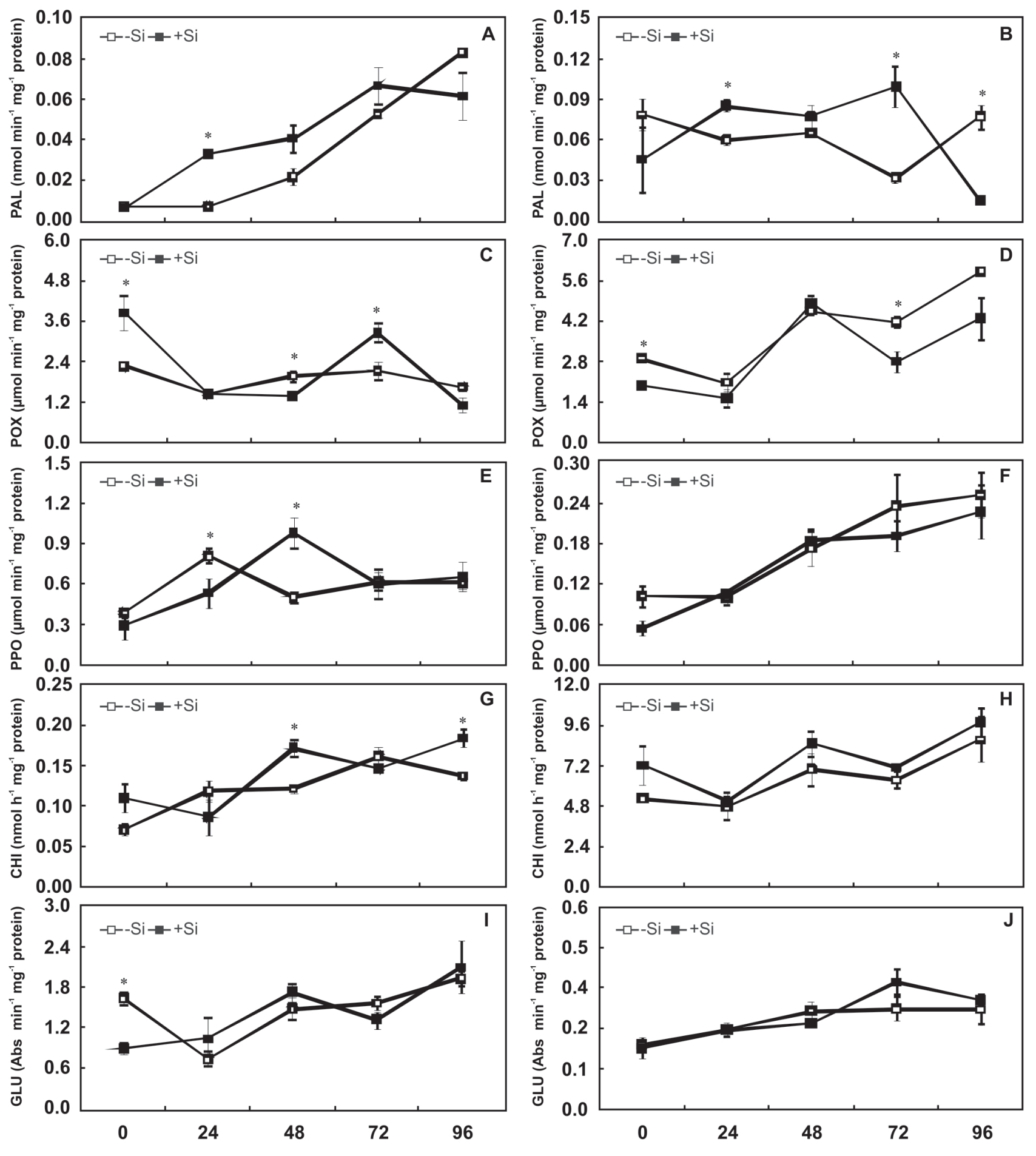

Hours after inoculation

Hours after inoculation

FIGURE 2 - Activities of phenylalanine ammonia-lyases (PAL), peroxidases (POX), polyphenoloxidases (PPO), chitinases (CHI) and $\beta$-1,3-glucanases (GLU) in the leaf sheaths of rice plants from cultivars BR-Irga 409 (A, C, E, G and I) and Labelle (B, D, F, H and J) not supplied (-Si) or supplied (+Si) with silicon $(\mathrm{Si})$ and inoculated with Rhizoctonia solani.

of supplying Si to rice plants aiming to enhance their level of basal resistance to foliar pathogens. For the rice- $R$. solani interaction, Si showed great potential to decrease the progress of sheath blight lesions concomitantly with an increase in the activities of the defense enzymes PAL, POX, $\mathrm{PPO}$ and $\mathrm{CHI}$. 


\section{ACKNOWLEDGEMENTS}

Prof. F. A. Rodrigues thanks $\mathrm{CNPq}$ for his fellowship. Dr. D. A. Schurt was supported by FAPEMIG. The authors thank Coordenação de Aperfeiçoamento de Pessoal de Nível Superior - CAPES, Conselho Nacional de Desenvolvimento Científico e Tecnológico - CNPq and Fundação de Amparo à Pesquisa do Estado de Minas Gerais for financial support.

\section{REFERENCES}

Bedendo IP, Prabhu AS (2005) Doenças do arroz. In: Kimati H, Amorim L, Rezende JAM, Bergamin Filho A, Camargo LEA (Eds.) Manual de Fitopatologia - Doenças das Plantas Cultivadas. Volume 2. $4^{\text {a }}$ Ed. São Paulo, SP. Editora Agrônomica Ceres. pp. 79-90.

Bélanger RR, Benhamou N, Menzies JG (2003) Evidence of an active role of silicon in wheat resistance to powdery mildew (Blumeria graminis f.sp. tritici). Phytopathology 93:402-412.

Bradford MN (1976) A rapid and sensitive method for the quantitation of microgram quantities of protein utilizing the principle of protein-dye binding. Analytical Biochemistry 72:248254.

Brunings AM, Datnoff LE, Ma JF, Mitani N, Nagamura Y, Rathinasabapathi B, Kirst K (2009) Differential gene expression of rice in responses to silicon and the rice blast fungus Magnaporthe oryzae. Annals of Applied Biology 155:161-170.

Cakmak L, Host WJ (1991) Effect of aluminum on lipid peroxidation, superoxide dismutase, catalase, and peroxide activity in root tip of soybean (Glycine max). Plant Physiology 83:463-468.

Campbell MM, Sederoff RR (1996) Variation in lignin content and composition. Plant Physiology 110:3-13.

Chance B, Maehley AC (1955) Assay of catalases and peroxidases. Methods in Enzymology 2:764-775.

Chittoor JM, Leach JE, White FF (1999) Induction of peroxidase during defense against pathogens. In: Datta SK, Muthukrishnan S (Eds.) Pathogenesis- Related Proteins in Plants. Boca Raton, FL, USA. CRC Press. pp. 171-193.

Dallagnol LJ, Rodrigues FA, DaMatta FM, Mielli MVB, Pereira SC (2011) Deficiency in silicon uptake affects cytological, physiological, and biochemical events in the rice-Bipolaris oryzae interaction. Phytopathology 101:92-104.

Dallagnol LJ, Rodrigues FA, Mielli MVB, Ma JF, Datnoff LE (2009) Defective active silicon uptake affects some components of rice resistance to brown spot. Phytopathology 99:116-121.

Datnoff LE, Rodrigues FA, Seebold KW (2007) Silicon and Plant Disease. In: Datnoff LE, Elmer WH, Huber DM (Eds.) Mineral Nutrition and Plant Disease. St. Paul, MN, USA. APS Press. pp. 233-246.

Dhingra OD, Sinclair JB (1995) Basic Plant Pathology Methods. Boca Raton, FL, USA. Lewis Publishers.

Gomez KA, Gomez AA (1994) Statistical Procedures for Agricultural Research. $2^{\text {nd }}$ Ed. New York, NY, USA. John Wiley.
Harman GE, Hayes CK, Lorito M, Broadway RM, Pietro AD, Peterbauer C, Tronsmo A (1993) Quitinolytic enzymes of Trichoderma harzianum: purification of quitobiosidase and endoquitinase. Phytopathology 83:313-318.

Kar M, Mishra D (1976) Catalase, peroxidase, and polyphenoloxidase activities during rice leaf senescence. Plant Physiology 57:315-319.

Keen NT, Yoshikawa M (1983) $\beta$-1,3-endoglucanase from soybean releases elicitor active carbohydrates from fungus cell walls. Plant Physiology 71:460-465.

Kim SG, Kim KW, Park EW, Choi D (2002) Silicon-induced cell wall fortification of rice leaves: a possible cellular mechanism of enhanced host resistance to blast. Phytopathology 92:1095-1103.

Korndörfer GH, Pereira HS, Nolla A (2004) Análise de Silício: Solo, Planta e Fertilizante. Uberlândia, MG, Brazil. Universidade Federal de Uberlândia.

Liang Y, Zhang W, Chenc Q, Ding R (2005) Effects of silicon on $\mathrm{H}^{+}$ATPase and $\mathrm{H}^{+}$PPase activity, fatty acid composition and fluidity of tonoplast vesicles from roots of salt-stressed barley (Hordeum vulgare L.). Environmental and Experimental Botany 53:29-37.

Liang YC, Hua HX, Zhu YG, Zhang J, Cheng CM, Romheld $\mathrm{V}$ (2006) Importance of plant species and external silicon concentration to active silicon uptake and transport. New Phytologist 172:63-72.

Lever M (1972) A new reaction for colorimetric determination of carbohydrates. Analytical Biochemistry 47:273-279.

Ma JF, Tamai K, Ichii M, Wu GF (2002) A rice mutant defective in Si uptake. Plant Physiology 130:2111-2117.

Ou SH (1985) Rice diseases. $2^{\text {nd }}$ Ed. Kew, England. Commonwealth Mycological Institute.

Roberts WK, SelitrennikoffCP(1988) Plant and bacterial chitinases differ in antifungal activity. Journal of Genetic Microbiology 134:169-176.

Rodrigues FA, Datnoff LE, Korndörfer GH, Seebold KW, Rush MC (2001) Effect of silicon and host resistance on sheath blight development in rice. Plant Disease 85:827-832.

Rodrigues FA, Jurick WM, Datnoff LE, Jones JB, Rollins JA (2005) Silicon influences cytological and molecular events in compatible and incompatible rice-Magnaporthe grisea interactions. Physiological and Molecular Plant Pathology 66:144-159.

Rodrigues FA, McNally DJ, Datnoff LE, Jones JB, Labbé C, Benhamou N, Menzies JG, Bélanger RR (2004) Silicon enhances the accumulation of diterpenoid phytoalexins in rice: a potential mechanism for blast resistance. Phytopathology 94:177-183.

Rodrigues FA, Vale FXR, Datnoff LE, Prabhu AS, Korndörfer GH (2003) Effect of rice growth stages and silicon on sheath blight development. Phytopathology 93:256-261.

Rodrigues FA, Duarte HSS, Domiciano GP, Souza CA, Korndörfer GH, Zambolim L (2009) Foliar application of potassium silicate on the control of soybean rust. Australasian Plant Pathology 38:366-372.

Rush MC, Lee FN (1992) Sheath blight. In: Webster RK, Gunnell PS (Eds.) Compendium of Rice Diseases. St. Paul, MN, USA. APS Press. pp. 22-23. 
Shaner G, Finney RE (1977) The effect of nitrogen fertilization on the expression of slow-mildewing resistance in Knox wheat. Phytopathology 67:1051-1056.

Torres MA, Jones JDG, Dangl JL. (2006) Reactive oxygen species signaling in response to pathogens. Plant Physiology 141:373378.
Xavier Filha MS, Rodrigues FA, Domiciano GP, Oliveira HV, Silveira PR, Moreira WR (2011) Wheat resistance to leaf blast mediated by silicon. Australasian Plant Pathology 40:28-38.

Zucker M (1965) Induction of phenylalanine deaminase by light and its relation to chlorogenic acid synthesis in potato tuber tissue. Plant Physiology 40:779-778.

TPP-2014-0088

Submitted: 7 June 2014

Revisions requested: 14 July 2014

Accepted: 3 August 2014

Section Editor: Marciel J. Stadnik 